\title{
Meeting Gerald Caplan
}

\author{
Gordon Langley
}

There is no better living example of the axiom that chronological age is a poor indicator of performance than Gerald Caplan. After a distinguished 20 years in a chair at Harvard and now twice retired, once from Harvard and once from the University Department of Child Psychiatry in Jerusalem, he still works as the Scientific Director of a private charitable trust, the Jerusalem Family Centre. A recent editorial (Cutler, 1993) described him as the father of community mental health. Now in his late seventies he is still keenly interested in preventive psychiatry in his chosen field (see below), and still publishes, sometimes with his daughter Ruth a medical historian (Caplan, 1993; Caplan \& Caplan, 1993).

I met Professor Caplan while in Jerusalem for other purposes. As a trainee I had read and admired Principles of Preventive Psychiatry (Caplan, 1964) and so I approached Professor Caplan who I had been informed by the College lived there. We eventually met on my last day in Israel, on his return from a seminar in Spain.

He spoke eagerly and enthusiastically of his efforts over the last 10 years to help Jerusalem Jewish children whose parents were contemplating divorce. His aim is not only to help those who are clinically referred, but also to seek out, and offer primary prevention to, a high risk subgroup of such children. Divorces in Israel pass through one of two Courts, Rabbinic, for all Jews, or Secular. Divorce laws are liberal, but each case is examined stringently by a court welfare officer and a panel of three Rabbis.

The services of school counsellors, psychologists, and doctors are generally available as well as those of two private resources (Shiluv - the Family Social Casework Agency and the Jerusalem Divorce Mediation Service) helping families in conflict. The Rabbis, in their Courts, have over the years developed their own expertise and it has taken Professor Caplan time and effort to build with them a relationship of mutual trust. The Rabbinic Courts were initially reluctant to accept clinical contributions towards their decision making. Then they accepted written evidence on difficult cases, and as time passed, increasingly, called Professor Caplan in person. This facilitated further mutual learning and trust. Gaining access to children who were not clinically referred, or to their records, has been more difficult, because of the confidentiality of the Court proceedings. Such access was necessary if criteria were to be found by which children could be divided, by triage, into three groups:

- low risk group with no need for professional attention

- a middle group, in which clinical referral was not yet mandated, but who could benefit from help (primary prevention), and

- a third group, so disturbed as to be beyond preventive help.

If this could be achieved, limited services could be focused on those most in need. In the last year, the Courts have accepted Professor Caplan's presence on a wider basis, as an informal observer who is sometimes asked for specialist advice. Problems remain with the formalisation of a defined 'control' group, but progress is being made.

Issues of child abuse commonly occur in these proceedings and Professor Caplan has found it difficult to tell whether some children are telling the truth, and to what degree their 'truth' is influenced by parents wishing the child to support their own case.

Other efforts towards prevention, in addition to clinical practice with referred cases, include:

- never closing a case file (so that after initial sessions clients can call for advice and gain free access, in person, to Professor Caplan)

- the education and training of concerned professionals

- mobilisation of non-professional mutual support groups

- the preparation of three guides for parents contemplating divorce on how to tell their children; advice to those who have divorced in recent years, and an information sheet for divorcing parents.

These pamphlets have proved effective in distributing information, and are popular. Attempts to train professionals engaged in a wider spectrum of care has met with some resistance because service directors felt that workers were being led away from their more general duties.

Much has already stemmed from Professor Caplan's work, but unless the high risk individual can be identified from the total population at risk, demand is likely to outstrip supply. Specific and effective forms of intervention need to be chosen. It is interesting that Professor 
Caplan, after many years of exploring global factors in the genesis of mental ill health, is now adopting a focused approach.

Pathogenic factors so far identified in the children of Jerusalem Jewish divorcees include: quarrelling parents; parental conflict over custody; one parent recruiting the child to take sides; parents using the child as an intermediary; parents who communicate the event of divorce late or not at all; abandonment by the non-custodial parent; low income and privation in the home; frequent changes of domicile by custodial parent; the effects of the stigma of divorce; the effects of divorce on heightening sexual curiosity in children (See Caplan, 1993 for more detail).

\section{Afterthoughts}

What is impressive about Gerald Caplan's present work is the impact of a small nuclear team (Professor Caplan, Ruth Caplan, a part-time psychologist, and a secretary). He writes that he spends no time on routine case conferences yet, in addition to his educational and preventive programme, he manages a case load of 580 "without undue strain" (Caplan, 1993). Nevertheless, all cases are interviewed routinely by both Gerald and Ruth Caplan, and their day to day meetings provide opportunity for informal discussion. They have worked together for many years and "share a common verbal and nonverbal language as well as a keen appreciation of each other's areas of unique expertise" (Caplan, personal communication). Personal strain is limited, not only by moving from concern with global prevention to a focused approach, but also by a high level of expertise and mutual understanding.

Contrast this with the present approach in England. It is recognised by clinicians, but not always by purchasers, that many conditions in psychiatry need a tertiary specialised approach if they are to be expertly treated (Beasley et al 1996). Specialised services, often provided at supra-Health Authority levels are in competition for resources with generalised, wider spread local services that are often less expensive. Unless wise decisions are made, the provision of general services may limit the availability of expertise - spreading the cake thinly. The provision of care within the community is no exception to this conflict. Standard, low intensity, case management, as in the now universally applied Care Programme Approach is not as effective as Assertive Community Treatment directed towards a smaller high risk population by a team of workers (Marshall, 1996). Even when Health Service workers target vulnerable populations this is not enough. In one study (Conway et al 1994) medical and community nursing interven- tion reduced symptoms in schizophrenics discharged from hospital but did not improve social functioning. Provision of work, social contact and accommodation is also required, again in competition with other resources. Unless a comprehensive service is appropriately targeted on specific vulnerable groups the desired results will not be achieved. Tyrer et al (1995) describe the results of implementing a community Care Programme Approach for a randomised group of highly vulnerable patients in a socially deprived area of London. Keyworkers maintained contact with patients fortnightly but hospital admissions increased compared with the group on standard care. That should not be a criticism if the admission was in the patient's best interests but only if it were necessitated by lack of community resources. This is not to say that there is no focused case work. Clearly there are many as, for example, described by Murray (1995) but there is a limiting conflict between detailed work and comprehensive cover that has to be managed.

Although prevention is clearly an important component of the UK studies cited above, neither secondary nor primary prevention is ever mentioned as such. Perhaps clinicians were too saturated with the work of treatment to spend time thinking about the prevention aspects of their work.

Neither a broad front nor an insufficiently resourced targeted approach is necessarily a satisfactory solution to clinical problems. Professor Caplan's work, and to an extent the studies cited above, show the advantages of a focused approach. A nationally organised service, in addition to being comprehensive, must address priorities (Langley, 1983), and also find time for the teaching and practice of specialised and focused skills.

Another contrast is between the small size and informal communications of Professor Caplan's team compared with a busy, and often ever changing, Community Mental Health Team in the UK, dealing with a wide range of community psychiatric problems. A diversity of problems calls for a diversity of skills; and individual patient care delivered by more than one member of the team needs coordination; this means communication; which means meetings where the difficulty in gathering members rises exponentially with the numbers involved. High staff turnovers compound the problem. More clinical meetings (and management meetings, and the time spent in travelling to dispersed community sites) means more time away from face-to-face contact with patients. So it is easy to be "busy doing nothing' i.e. meeting and travelling to the detriment of face-to-face contact with patients. Professor Caplan, with his small team and focused approach, is in an enviable position. 
In the UK there is a delicate balance to be achieved by managers who decide priorities and by clinicians who organise training and clinical responsibilities. Professor Caplan's work suggests that we must be careful to preserve special skills and interests and avoid expecting too much from the generalist, especially at a time where clinicians are constantly asked to give more (work and quality) for less (departmental money).

If such an expert as Gerald Caplan has accepted the wisdom of a narrow front expert approach perhaps psychiatry in the UK should carefully consider whether, in trying to do so much in the community we achieve less than our high ideals intend.

\section{References}

BEASLEY, J., BROCKINGTON, I. F. \& CRISP, A. (1996) Survey of highly specialised psychiatric services. Psychiatric Bulletin, 20, 129-130.

Caplan, G. (1964) Principles of Preventive Psychiatry. New York: Basic Books.
- (1993) Organisation of preventive psychiatry programmes. Community Mental Health Journal, 29. 367-395.

- \& CAPLAN, R. (1993) Mental Health Consultation and Collaboration. San Francisco: Josey-Bass.

Conway, A., MElzER, D. \& HAlE. A. S. (1994) The outcome of targeting community mental health services: evidence from the West Lambeth schizophrenta cohort. British Medical Journal, 308, 627-630.

CUTLER, D. L. (1993) Roots, trunks, branches and blossoms: a preface to Gerald Caplan's Preventive Psychiatry Programme. Community Mental Health Journal, 29, 363-365.

LANGLEY, G. E. (1983) It may be 'community' but is it comprehensive: a wrong question? The Bulletin of the Royal College of Psychiatrists, 7, 62-66.

MARSHALL, M. (1996) Case management: A dublous practice, British Medical Journal, 312. 523-524.

MURRAY, J. (1995) Prevention of Anxiety and Depression in Vulnerable Groups. London: Gaskell.

TYRER, P., MORGAN, V., VAN HORN, E., et al (1995) The Lancet, 345, 756-759.

G. E. Langley, Hanningfields, Warborough Hill, Kenton, Exeter, Devon EX6 8LR 